\title{
Improving Vocational Skills on Peanuts Plant of Light Mental Retardation Children at Class IX SLBN I Padang
}

\author{
Tria Handayani , Yarmis Hasan \\ Universitas Negeri Padang \\ tria_handayani@gmail.com
}

\begin{abstract}
This research is motivated by problems that researchers found in class IX light mental retardation in SLB Negeri I Padang in June 2019. Learning the skills to grow peanuts in light intellectual retardation children, it seems that the work process of children is still not good and right. The objectives of this study are 1 . To find out the process of improving peanut planting skills through a demonstration-based method of task analysis in light IX retard children in SLBN 1 Padang. 2. Prove that lightly mental retardation children are skilled at growing groundnuts through demonstration-based methods of task analysis. This type of research is a classroom action research conducted in the form of collaboration between researchers and classroom teachers. As research subjects, two children with light mental retardation grade IX C. Data obtained through observation, and tests of deeds. Then analyzed qualitatively translated through test results. The results of the study after being treated for 7 (seven) meetings showed that the initial ability before the treatment of planting peanuts by BY $28 \%$, and $\mathrm{ML}$ $39 \%$. While at the end of the first cycle, BY's ability increased (63\%), and ML (68\%). In cycle II the ability of BY increased to (89\%) and ML (93\%). Each cycle begins with planning, implementation, observation, analysis, and reflection. It can be concluded that the implementation of learning by using a method of analysis based on task analysis can improve peanut planting skills in children with intellectual retardation in class IX in SLB Negeri I Padang.
\end{abstract}

Keywords: vocational skills, demonstration methods based task analysis, mental retardation children.

\section{INTRODUCTION}

Every human being is created differently. Both physically, character, talent, until the ability possessed. One of the reasons God created us is different so that we can take roles according to our abilities and complement each other. Developing that, then they need to get an education. As stipulated in the Law of the Republic of Indonesia Number 20 of 2003 in article 12, it is found that "every student has the right: to get an education and be taught by educators, to get educational services according to their talents, interests, and abilities.

Get scholarships for high achievers whose parents are unable to pay for their education, get tuition fees for parents who cannot afford their education, move to educational programs on the same track and other educational units, complete educational programs according to the pace of learning and do not deviate from the provisions deadline set ".Education is essential for children with special needs. One child with 
special needs is light mental retardation. Children with mental retardation require guidance and direction, according to their characteristics and abilities. The learning aspects of mentally mental retardation children are unique because children's limited thinking ability influences them. This condition greatly influences the specific empowerment approach strategy. For that, the development of excellent skills is given to mentally mental retardation children to support their independence after adulthood. The importance of learning skills is achieving better independence. For mentally mental retardation children, rehabilitation guidance is needed repeatedly and comprehensively including physical, mental, social and vocational aspects. Based on the purpose of vocational skills education for mentally mental retardation children, it is intended that children can live independently, economically, in the community. So that mentally mental retardation children can meet their daily needs, and the future is adjusted to their abilities and degrees of disability. Children with intellectual disabilities as children, in general, have the right and need to actualize their potential to be able to live independently. But in the fulfillment of these things, they experience obstacles because of the limitations of the function of intellectual intelligence who are under their chronological age. Therefore the mentally mental retardation child will show the actualization of intellectual functions and abilities in adaptive behavior under his age. To help the attainment of the goals of vocational education for mentally mental retardation children, in order to be independent in social life, the mentally mental retardation child is equipped with simple basic skills, because not all and it is not easy for mentally mental retardation children to get a job after they are not in school anymore (18 years). In accordance with the curriculum used at school, Integrated Education is a curriculum unit for mental retardation children. Therefore the mentally mental retardation child will show the actualization of intellectual functions and abilities in adaptive behavior under his age. To help the attainment of the goals of vocational education for mentally mental retardation children, in order to be independent in social life, the mentally mental retardation child is equipped with simple basic skills, because not all and it is not easy for mentally mental retardation children to get a job after they are not in school anymore (18 years). Under the curriculum used at school, the Integrated Education curriculum unit for mental retardation children. Therefore the mentally mental retardation child will show the actualization of intellectual functions and abilities in adaptive behavior under his age. To help the attainment of the goals of vocational education for mentally mental retardation children, in order to be independent in social life, the mentally mental retardation child is equipped with simple basic skills, because not all and it is not easy for mentally mental retardation children to get a job after they are not in school anymore (18 years). Under the curriculum used at school, namely the Integrated Education Unit curriculum for mentally mental retardation children. Because not all and it is not easy for mentally mental retardation children to get a job after they are not in school anymore (18 years). Under the curriculum used at school, namely the Integrated 
Education Unit curriculum for mentally mental retardation children. Because not all and it is not easy for mentally mental retardation children to get a job after they are not in school anymore (18 years). Under the curriculum used at school, namely the Integrated Education Unit curriculum for mentally mental retardation children.

Based on a preliminary study is conducted on Thursday, January 24, 2019, in SLBN 1 Padang. Researchers looked at some polybags of plants, which were in front of class IX C. In one polybag, dry plants were seen, and the soil conditions were slightly cracked. Researchers sought information about the plants from the class teacher. Based on information from the class teacher that the plant is peanuts. Peanuts are planted when learning Natural Sciences and when the child is doing self-development activities.

Regarding the methods used when teaching to grow peanuts are lecture and demonstration methods, but the teacher demonstrates not all steps in the planting of peanuts. As a result, many steps in planting peanuts are not properly done by children. When conducting the initial ability test on two children, who sat in class IX C, the child did not know all the tools and materials used in growing peanuts, and regarding the steps in planting peanuts, students do not understand how to plant peanuts.

Under the characteristics of learning for light mental retardation children, this can be improved through a task analysis based demonstration method. The method of demonstration based on task analysis is a method of demonstration and work steps that are used, ie the task is to specify in detail the steps of work by conveying verbally followed by a demonstration. In connection with the above, the writer and the class teacher want to continue their peanut planting skills that have not been maximized, with the problems and ideas that the authors found, the writer wants to conduct a study entitled "Improving Peanut Planting Skills through demonstration methods based on task analysis based on light mental retardation classroom children IX (Classroom action research in SLBN 1 Padang ") .

\section{METHOD}

This type of research is a classroom action research conducted in the form of collaboration between researchers and classroom teachers. As research subjects, two children with light mental retardation grade IX C. Data obtained through observation, and tests of deeds. Then analyzed qualitatively translated through test results.

\section{RESULTS AND DISCUSSION Results}

This research was conducted in two cycles. Cycle one is from 15 to 29 June 2019. While the second cycle starts from 1 July to 6 July 2019. Learning is done using a demonstration method based on task analysis. Then take action that starts from the initial activities, core activities and final activities. Each meeting held a test under what was taught. The end of the cycle is the report of the collaborator's observations, then the collaborator and class teacher analyze the activities and results that have been achieved 
and then hold reflections to determine the next course of action. From the results of data reduction presented in the narrative form of the learning process in improving peanut planting skills, the research questions in chapter I are answered, namely:

1. Can the skill of growing peanuts in class IX mental retardation ankles be developed through a demonstration method based on task analysis in SLBN I Padang?

The results of the data analysis on the graph show that the demonstration method based on task analysis in implementing learning can improve peanut planting skills.

a. At the end of the cycle I the child did not get a good grade BY 64\%, and ML gained $70.2 \%$.

b. In cycle II the child has gotten good grades. At the end of the meeting, BY 89\% and ML 93\%. Where the child can already prepare tools and materials and can already grow peanuts according to the steps.

The test results are carried out to determine the ability of children to improve their peanut planting skills. Based on the results of the initial ability before being given optimal action through a demonstration-based method of task analysis, it can be seen in the appendix that the results of the child's initial ability test are still low in implementing peanut planting skills. An illustration of the ability to grow peanuts through a task analysis based demonstration method can be seen as follows:

The ability to grow peanuts through a demonstration method based on task analysis based on the ability test alawl (before given action) As stated in the research grid, what will be achieved is to improve the skills of planting peanuts through a task analysis based demonstration method. As for the initial ability scores of light mental retardation children in class IX before being given treatment can be seen in the graph below:

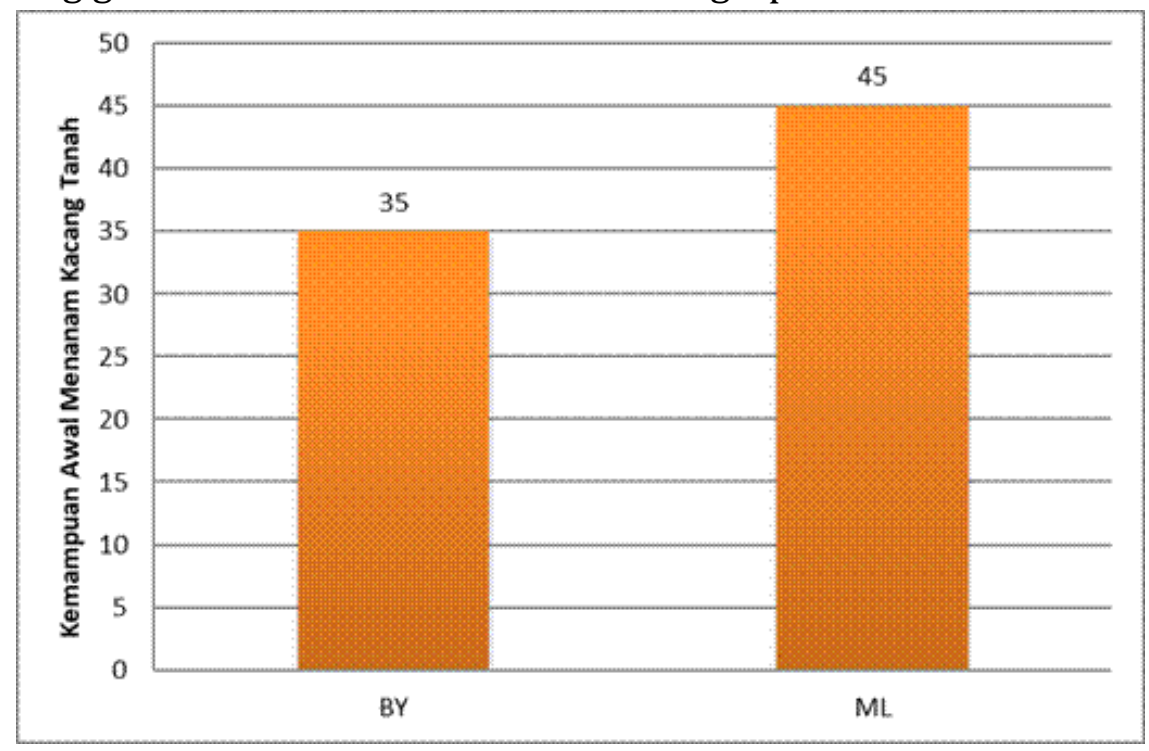

1. Graph I. Early Childhood Ability to Grow Peanuts 
From the graph above, it is known that the ability of light mental retardation children to grow peanuts is still low at BY 35\% and ML 45\%. Capability results data. The beginning can be seen in the attachment. After the initial ability is known, it is necessary to improve the skills of planting mentally mental retardation peanuts by using classroom action research. The ability grow peanuts through a demonstration method based on task analysis after giving action in cycle I.

In Cycle I, the class teacher gave an action in learning to plant peanuts through a demonstration method based on task analysis. The task analysis based demonstration method is a way in which all learning is modeled for each step in detail with the aim that the child understands every step in the learning. If the child cannot, it will be demonstrated and guided again. Activities carried out based on the steps that have been set in cycle I can be seen in graph 4.2

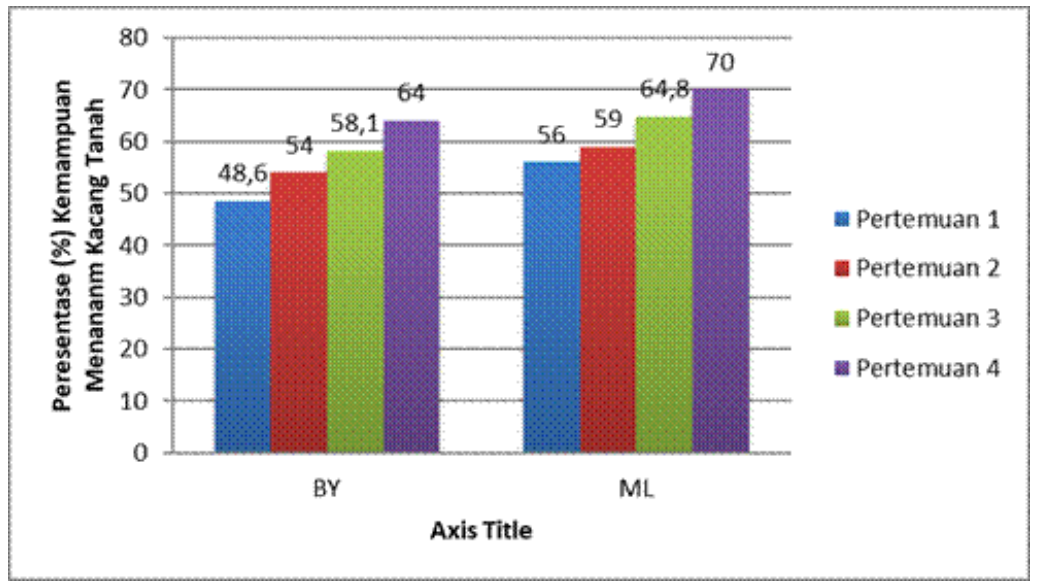

2. Graph 2. Recapitulation of the value of the ability to grow peanuts through a demonstration method based on task analysis in cycle I

Based on the graph above, it can be seen that in the first cycle there was an increase, where BY in the initial ability obtained a value at the first meeting to the fourth meeting 48\%, 54\%, and ML 56\%, 59\%, 64\%, 70\%.

Based on data obtained from the four meetings above, it can be seen that in terms of value, children experience improvement after being given action through a task analysis-based demonstration method, even though the results or values obtained are not optimal. Therefore, the agreement between collaborator and class teacher is reflected to be continued in cycle II.

In cycle II, collaborators provide learning that children have not mastered from the first cycle to find out the child's ability to plant peanuts through the method of task analysis based demonstarsi. The increase in children's ability to grow peanuts in the second cycle of children can be described as follows in graph 4.3 : 


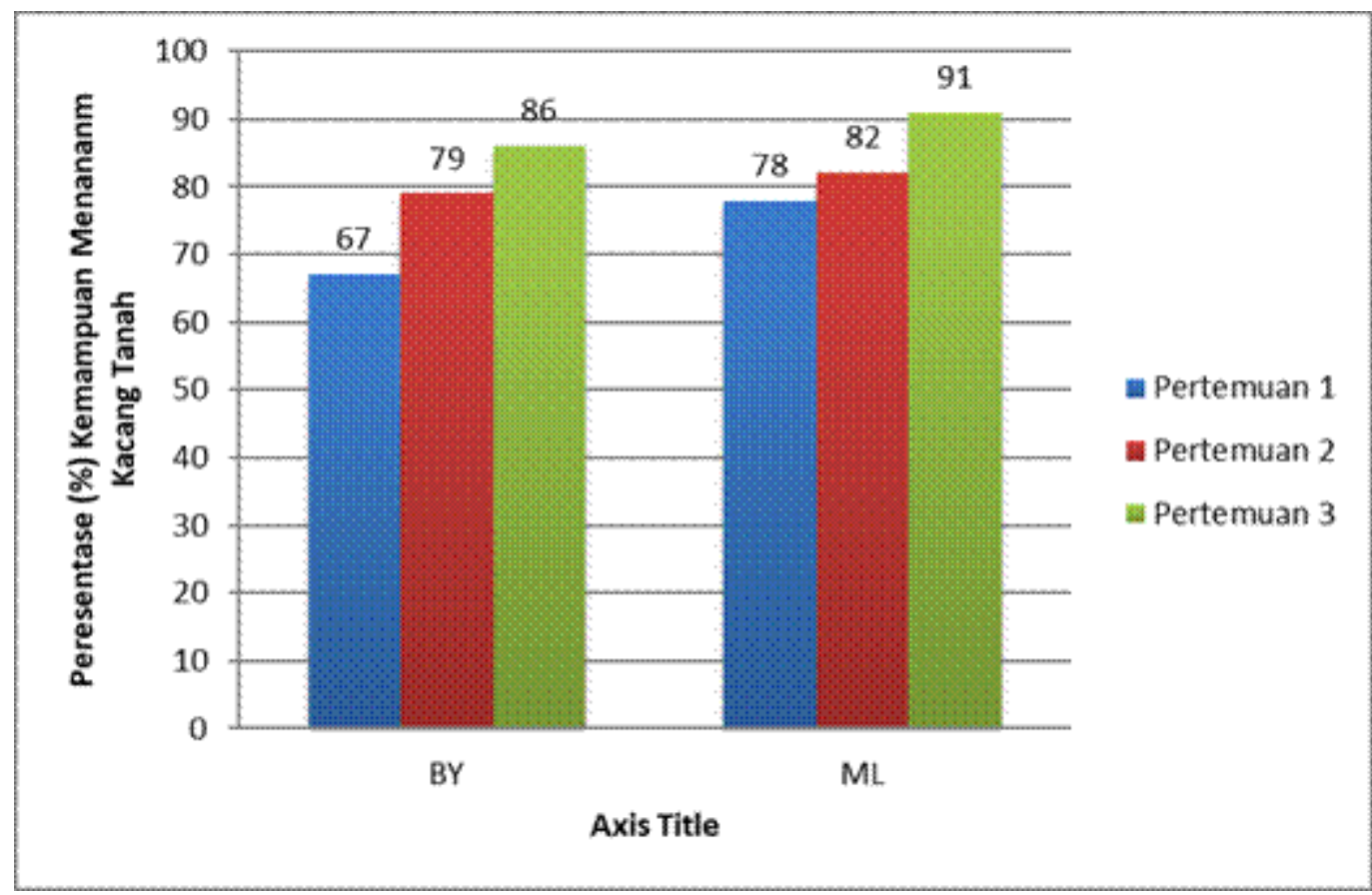

\section{Graph 3. Recapitulation of the value of the ability to grow peanuts through a} demonstration method based on task analysis in cycle II

\section{CONCLUSION}

Based on the results obtained from the recapitulation of the data above, it can be seen that the child's ability to plant peanuts through demonstration-based methods of task analysis is increasing. In the second cycle BY obtained a value of $67 \%, 79 \%, 86 \%$ and ML 78\%, 82\%, 93\%. From the results obtained above it can be seen that the value of children has increased significantly. The highest value was achieved by $86 \%$ and ML by 93\%. Although children still need a little guidance in several aspects.

Based on the data above, it means that cycle I and cycle II can be said to be independently controlled by children. Because in general the steps to grow peanuts can be done correctly by children. Then the action is stopped in this second cycle.

\section{REFERENCES}

Djamarah, Bahri, S., \& Zain, A. (2006). Strategi Belajar Mengajar. Jakarta: Reineka Cipta. Efendi, M. (n.d.). Pengantar Psikopedagogik Anak Berkelainan. Malang: Bumi Akasara.

Kemis. (2013). Pendidikan Anak Berkebutuhan Khusus Anak Tunagrahita. Jakarta: Luxima Metro Media.

Kemis, \& Ambomide, M. T. (2015). Meningkatkan Hasil Belajar Siswa Dengan Metode Demonstrasi Pada Mata Pelajaran IPA. Kreatif Tadulako, 4(5).

Kemis, \& Rosnawati, A. (2013). Pendidikan Anak Berkebutuhan Khusus Tunagrahita. Jakarta: Luxima Metro Media.

Kosasih. (2012). Cara Bijak Memahami Anak Berkebutuhan Khusus. Banadung: Yhara Widia. 


\section{Edutec \\ Journal of Education And Technology \\ 2597-9221 (Online)}

Maleong, L. (1998). Penelitian Kualitatif. Jakarta: Erlangga.

Marlina. (2009). Asesmen Pada Anak Berkebutuhan Khusus. Padang: UNP Press. 